\title{
In vitro evaluation of PVA gels loaded with Copaiba Oil and Duotrill ${ }^{\circledR}$
}

\author{
Ingrid Cristina Soares Pereira ${ }^{1}$ (D), Natália Rodrigues Rojas dos Santos ${ }^{1}$, Antonieta Middea ${ }^{2}$, \\ Edlene Ribeiro Prudencio ${ }^{3}$, Rosa Helena Luchese ${ }^{3}$, Ana Paula Duarte Moreira ${ }^{4 *}$ \\ and Renata Nunes Oliveira ${ }^{1}$
}

\author{
'Departamento de Engenharia Química - DEQ, Instituto de Tecnologia - IT, Universidade Federal Rural do \\ Rio de Janeiro - UFRRJ, Seropédica, RJ, Brasil \\ ${ }^{2}$ Centro de Tecnologia Mineral - CETEM, Rio de Janeiro, RJ, Brasil \\ ${ }^{3}$ Departamento de Tecnologia de Alimentos - DTA, Instituto de Tecnologia - IT, Universidade Federal \\ Rural do Rio de Janeiro - UFRRJ, Seropédica, RJ, Brasil \\ ${ }^{4}$ Programa/Departamento de Engenharia Metalúrgica e de Materiais, Escola Politécnica - POLI, \\ Instituto Alberto Luiz Coimbra de Pós-Graduação e Pesquisa de Engenharia - COPPE, \\ Universidade Federal do Rio de Janeiro - UFRJ, Rio de Janeiro, RJ, Brasil \\ *duarteap@gmail.com
}

\begin{abstract}
Enrofloxacin can be slowly delivered through polymeric systems and the addition of oil could increase the polymeric gels hydrophobicity and help the continuous release. The present work intended to develop and characterize microstructurally (XRD and FTIR) and in vitro (swelling and antimicrobial tests) the PVA hydrogels loaded with copaiba oil and Duotrill (enrofloxacin) to treat bacterial infections, as pyelonephritis, in the veterinary field. Duotrill ${ }^{\circledR}$ and oil combined diminished the gels degree of crystallinity and it was observed interaction between phases due to a new band found only in PVA hydrogels loaded with copaiba oil and Duotrill (PVA-D-O) FTIR spectrum. The samples with oil swelled less than samples without it, where copaiba oil altered the samples' hydrophilicity. PVA-D-O presented lower weight loss and higher gel fraction than PVA, indicating the loaded material increased the gels stability. All samples containing oil and Duotrill $^{\circledR}$ inhibited S. aureus.
\end{abstract}

Keywords: PVA, hydrogel, copaiba oil, enrofloxacin, in vitro.

How to cite: Pereira, I. C. S., Santos, N. R. R, Middea, A., Prudencio, E. R., Luchese, R. H., Moreira, A. P. D., \& Oliveira, R. N. (2019). In vitro evaluation of PVA gels loaded with Copaiba Oil and Duotrill ${ }^{\circledR}$. Polimeros: Ciência e Tecnologia, 29(3) e2019039. https://doi.org/10.1590/0104-1428.03719

\section{Introduction}

Pyelonephritis is a name used to describe an inflammatory process of the pelvis and renal parenchyma originated by bacterial infections all over the lower urinary tract. These bacterial infections are generally caused by aerobic bacteria, e.g. Escherichia coli and Staphylococcus sp., and rarely by species of Proteus, Streptococcus, Klebsiella and Enterobacter $^{[1,2]}$. There is a wide variety of antibiotics to treat bacterial diseases in animals, specially dogs and cats. Consequently, there is also an increase of intoxication due to the incorrect use (overdose) of this medicine. Some cases, the drugs' collateral effects and toxins could lead to death ${ }^{[3]}$. One possible alternative to avoid poisoning is the use of drug delivery systems (DDS), e.g. hydrogels ${ }^{[4]}$.

Stauffer and Peppast ${ }^{[5]}$ developed polyvinyl alcohol (PVA) hydrogels (3D networks of hydrophilic polymers) with structural integrity by physical crosslinking ${ }^{[5]}$, using freeze-thawing method ${ }^{[6]}$. The development of PVA hydrogels by freeze-thawing are based on the polymer's hydroxyl groups, which form crystallites through of intra- and inter-chain hydrogen bonding ${ }^{[7]}$.

The PVA physical hydrogels are biocompatible, stable at room temperature, ease form film by solution casting and suffer natural biodegradation under physiological conditions $^{[7-9]}$ Biodegradation or erosion mechanism of PVA physical hydrogels is essential to drug delivery by implantable biomaterials ${ }^{[9]}$. Among PVA gels used as DDS, there are: Jensen et al. ${ }^{[9]}$, who developed gels with high potential for drug delivery through spontaneous erosion ${ }^{[9]}$; Marques ${ }^{[10]}$ studied hydrogels loaded with ibuprofen and obtained gels with excellent mechanical propriety and an efficient controlled ibuprofen delivery ${ }^{[10]}$.

PVA hydrogels are usually combined it with antimicrobial agents to grant them this characteristic. Regarding natural materials with antimicrobial properties, Oliveira et al. ${ }^{[4]}$ had successfully loaded propolis (bee-based material) to PVA hydrogels ${ }^{[4]}$. In addition, bioactive oils are also able of 
delay the microbial activity, due to phenolic and terpenoids groups to which is attributed their antimicrobial activities ${ }^{[1]]}$. Brandelero et al. ${ }^{[12]}$ added copaiba and lemongrass oils directly to starch-polyvinyl alcohol-alginate device, which presented improved antimicrobial properties ${ }^{[12,13]}$. Kavoosi et al. ${ }^{[14]}$ developed gelatin/PVA hydrogel loaded with Zataria essential oil (ZO) for wound-dressing, obtaining increased the antimicrobial activities due to the addition of ZO, which also decrease the films' swelling ability. ZO probably contributed to the gels hydrophobicity due to its characteristics ${ }^{[12,14]}$. The essential oils have a nature hydrophobic due to substances that stimulate create region non-polar in the polymeric matrix. This efficiency is linked with rate of proportion between hydrophilic and hydrophobic of film, and with characteristics of the compounds added such as polarity or structural chemical ${ }^{[12,15]}$.

Copaiba oil, obtained from copaiba trees (Copaifera sp., Fabaceae), is a natural antimicrobial agent native from western Africa and South America (specifically from the Amazon, north of Brazil). The Amazon indigenous people use copaiba oil for treatment of various diseases, e.g. stomach ulcers and tonsillitis ${ }^{[16-18]}$. Antimicrobial studies of the copaiba oleoresin found its high potential as medicine ${ }^{[19]}$. Sachetti et al. ${ }^{[16]}$ observed that the oleoresin did not cause negative effects (toxicity) to rats, but further studies are necessary ${ }^{[16]}$. Copaiba oil could add the antimicrobial property and hydrophobicity to PVA hydrogels.

Among the hydrophilic drugs that could be added to PVA, there is Duotrill (commercial name), an enrofloxacin based antibiotic $^{[20]}$. The enrofloxacin is a fluoroquinolone used in the veterinary medicine. According to Vancutsem et al. ${ }^{[21]}$ the fluoroquinolones is efficient in the treatment of bacterial diseases in several animals, including birds, except to juvenile dogs and horses, since it effects their cartilage ${ }^{[21,22]}$. The enrofloxacin is excellent to treat pyelonephritis, since this antibiotic has a wide spectrum of action against Gram-negative (E. coli, Pseudomonas sp and Enterobacter sp) and some Gram-positive bacteria (Streptococcus $s p$ and Staphylococcus sp) and Mycoplasma and Chlamydia ${ }^{[2,20,22]}$. Enrofloxacin can be loaded to polymers to be slowly delivered, e.g. enrofloxacin loaded to Poly(3-hydroxybuty rate-co-3-hydroxyvalerate) (PHBV) microspheres showed delivery for 13 days and when inserted intramuscular, it was detected in rats' blood for 3 days. Nonetheless it could be inferred that the therapeutic concentration was maintained for long periods when enrofloxacin was delivered through PHBV microspheres ${ }^{[23]}$.

The goal of present work was to develop and characterize microstructurally and in vitro the PVA hydrogels loaded with copaiba oil and Duotrill (enrofloxacin) intended to treat bacterial infections in the veterinary field.

\section{Materials and Methods}

\subsection{Materials}

Polyvinyl alcohol - PVA, $\mathrm{M}_{\mathrm{w}}$ 85000-124000 Da and degree of hydrolysis $99 \%$, was purchased from Sigma Aldrich. The copaiba oil, natural product, was obtained commercially from Ashram Aquarius. Ethyl alcohol, 95\% purity, was purchased from Vetec. The Duotril ${ }^{\circledR}$ (drug) was obtained commercially from Laboratory Duprat in Brazil. All reagents described were used without further purification.

\subsection{Preparation of the samples}

The method employed to preparation of four samples distinct was based on Oliveira et al. ${ }^{[4]}$ The PVA pristine and PVA hydrogels containing duotril, oil and both oil and duotril were labelled PVA, PVA-D, PVA-O, PVA-D-O, respectively. PVA aqueous solution $(10 \% \mathrm{w} / \mathrm{v})$ was prepared by dissolution in $90^{\circ} \mathrm{C}$ for $4 \mathrm{~h}$, under mechanical stirring and it was named 'PVA'. The duotril was dissolved in distilled $\mathrm{H}_{2} \mathrm{O}$ at room temperature, under magnetic stirring and mixed to PVA solution. This sample was named 'PVA-Duotril' (PVA-D). The copaiba oil was associated to ethyl alcohol (molar ratio 1:1) at room temperature under magnetic stirring and after mixed to PVA solution. This sample was named 'PVA-Oil' (PVA-O). The samples composition is displayed in Table 1.

The duotril and the copaiba oil were mixed to PVA solution when it reached room temperature under stirring and it was named 'PVA-Duotril-Oil' (PVA-D-O). $10 \mathrm{~mL}$ of each final solution were poured in petri dishes (diameter of $90 \mathrm{~mm}$ ), and the samples were freeze-thawed (1 cycle of $16 \mathrm{~h}$ at $-16^{\circ} \mathrm{C}$ and $30 \mathrm{~min}$ at $25^{\circ} \mathrm{C}$ followed by 4 cycles of $1 \mathrm{~h}$ at $-16^{\circ} \mathrm{C}$ and $30 \mathrm{~min}$ at $25^{\circ} \mathrm{C}$ ). The samples were dried in room temperature afterwards.

\subsection{Microstructural analysis}

Microstructural characterization of dry samples was performed using Fourier Transform Infrared Spectroscopy (FTIR, PerkinElmer equipment, Spectrum 100 (COPPE/UFRJ), in the ATR mode, wavenumber range of $4000 \mathrm{~cm}^{-1}$ and $600 \mathrm{~cm}^{-1}$, 32 scans per samples and a spectral resolution of $4 \mathrm{~cm}^{-1}$ ) and X-ray diffraction analysis (XRD, Bruker-AXS D8 Advance

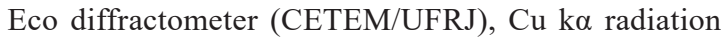
$(40 \mathrm{kV} / 25 \mathrm{~mA})$, in the $2 \Theta$ angle range of $10^{\circ}-60^{\circ}$, with a $0.01^{\circ}$ step size and a position-sensitive Lynx Eye XE detector with energy discrimination). The degree of crystallinity (Xc) of the samples evaluated by XRD was based on the area of crystalline peaks per area of crystalline and amorphous phases $^{[24]}$.

Table 1. Hydrogels samples composition.

\begin{tabular}{|c|c|c|c|c|}
\hline Sample & PVA (g) & $\mathrm{H}_{2} \mathrm{O}(\mathrm{mL})$ & Oil (mL) & Duotril (mg) \\
\hline PVA & 10 & 100 & 0 & 0 \\
\hline PVA-D & 10 & 95 & 0 & $50 \mathrm{mg} / 5 \mathrm{~mL} \mathrm{H}_{2} \mathrm{O}$ \\
\hline PVA-O & 10 & 95 & 5 & 0 \\
\hline PVA-D-O & 10 & 90 & 5 & $50 \mathrm{mg} / 5 \mathrm{~mL} \mathrm{H}_{2} \mathrm{O}$ \\
\hline
\end{tabular}




\subsection{In vitro analysis}

Swelling/Weight loss tests were adapted according to Oliveira et al. ${ }^{[4,25]}$ and Costa ${ }^{[26]}$. Each sample composition $(n=5)$ was evaluated, where the samples remained immersed in $10 \mathrm{~mL}$ saline solution (SS) for 4 days at room temperature, being weighed periodically (30 min, $1 \mathrm{~h}, 2 \mathrm{~h}, 3 \mathrm{~h}, 4 \mathrm{~h}, 24 \mathrm{~h}$, $48 \mathrm{~h}, 72 \mathrm{~h}$ and $96 \mathrm{~h}$ ). The samples were dried and weighted afterwards. The swelling degree (SD) and weight loss (WL) were calculated according to Equations (1) and (2), respectively. Furthermore, the samples' gel fraction (GF) percentage, was calculated, Equation (3).

$$
\begin{aligned}
& \mathrm{SD}=100 \times \frac{\mathrm{W}_{\mathrm{S}}-\mathrm{W}_{\mathrm{D}}}{\mathrm{W}_{\mathrm{D}}} \\
& \mathrm{WL}=100 \times \frac{\mathrm{W}_{\mathrm{D}}-\mathrm{W}_{\mathrm{DS}}}{\mathrm{W}_{\mathrm{D}}} \\
& \mathrm{GF}=100 \times \frac{\mathrm{W}_{\mathrm{DS}}}{\mathrm{W}_{\mathrm{D}}}
\end{aligned}
$$

The $\mathrm{W}_{\mathrm{S}}$ is the samples' weight at each interval time. Whereas, $\mathrm{W}_{\mathrm{D}}$ is the dry weight prior to swelling test and $\mathrm{W}_{\mathrm{DS}}$ is the dry weight after swelling ${ }^{[25-27]}$.

Antimicrobial activity of hydrogels was evaluated according to standard ASTM E2180-07 with some changes, using Staphylococcus aureus. In the initial step, a cell suspension of $S$. aureus (ATCC 6538) was prepared, adjusting the turbidity on the MacFarland scale to 5, that is equivalent to $10^{8}$ colony forming units per $\mathrm{mL}(\mathrm{CFU} / \mathrm{mL})$. Afterwards, one (1) $\mathrm{mL}$ of this suspension was diluted in $100 \mathrm{~mL}$ of agar paste to obtain concentration of $10^{6} \mathrm{CFU} / \mathrm{mL}$. The samples were placed on 24-well plates and each sample was added of 200 microliters of agar inoculated paste. The plates were incubated at $30^{\circ} \mathrm{C}$ for $24 \mathrm{~h}$. Thereafter, incubated samples were moved to Falcon tubes and it was added 1,8 $\mathrm{mL}$ of buffer solution. Subsequent decimal dilutions were prepared up to $10^{-4}$ and $S$. aureus survivability was evaluated on PCA agar using the micro-drop plate technique.

\subsection{Statistical analysis}

The statistical analysis was performed using the one-way ANOVA analysis and Tukey test. The ANOVA one-way analysis, 95\% significance level, was used to evaluate the parameter amount of drug and/or oil, with four levels: PVA, PVA-Drug, PVA-Oil and PVA-Oil-Drug. The gels' swelling capacity, weight loss and gel fraction were used as response data. Tukey test, $\alpha=0.05$, was conducted to determine if the difference between each pair was significant.

\section{Results and Discussions}

\subsection{Microstructural analysis}

The FTIR spectra of all samples, Figure 1, shows the comparison between PVA-D, PVA-O and PVA, as well as PVA-D-O with PVA-D and PVA-O. Table 2 summarizes the FTIR band assignments of the hydrogels produced as shown in Figure 1. PVA presents bands at: $3626 \mathrm{~cm}^{-1}$, $v(-\mathrm{OH})$, regarding inter- and intramolecular hydrogen bonds; $2942 \mathrm{~cm}^{-1}, v(-\mathrm{CH})$ from alkyl groups; $2915 \mathrm{~cm}^{-1}, v_{\text {as }}\left(\mathrm{CH}_{2}\right)$;
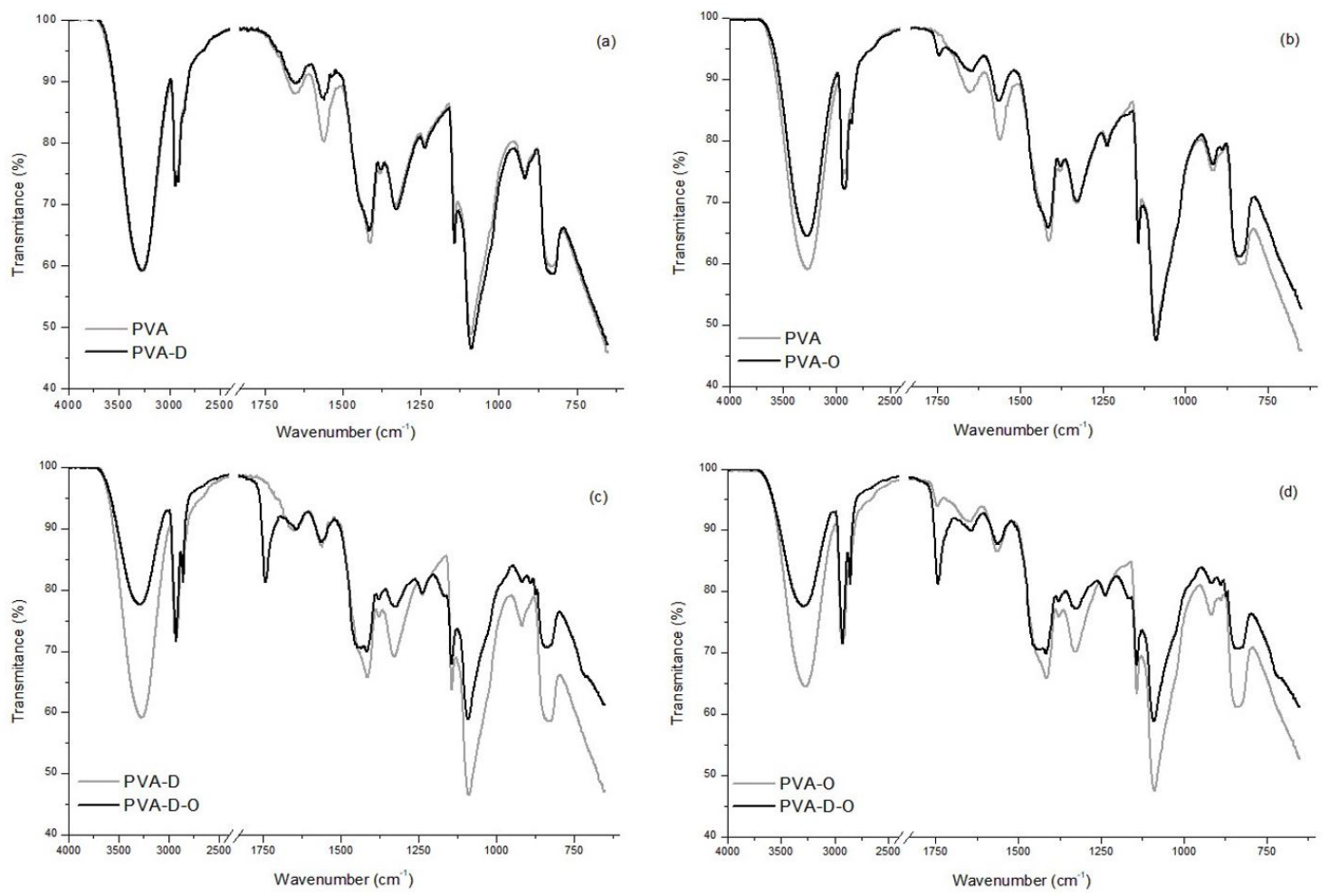

Figure 1. FTIR spectra of the samples: (a) PVA and PVA-D; (b) PVA and PVA-D; (c) PVA-D and PVA-D-O; (d) PVA-O and PVA-D-O. 
Table 2. FTIR wavenumbers and respective vibration modes of samples.

\begin{tabular}{|c|c|c|}
\hline Wavenumber $\left(\mathrm{cm}^{-1}\right)$ & Assignments & Sample \\
\hline 3626 & $\mathrm{O}-\mathrm{H}$ streching & PVA and PVA compounds ${ }^{[28-34]}$ \\
\hline 2942 & $\mathrm{C}-\mathrm{H}$ streching & \\
\hline 2915 & $\mathrm{CH}_{2}$ asymmetric streching & \\
\hline 1652 & $\mathrm{C}-\mathrm{H}$ streching & \\
\hline 1560 & $\mathrm{C}=\mathrm{C}$ streching & \\
\hline 1413 & $\mathrm{O}-\mathrm{H}$ bending & \\
\hline 1380 & combination of $(\mathrm{CH}+\mathrm{OH})$ groups & \\
\hline 1236 & $\mathrm{C}-\mathrm{H}$ bending & \\
\hline 1142 & stretching vibration related to crystallites formation & \\
\hline 1089 & $\mathrm{C}-\mathrm{O}$ streching of secondary alcohols; $\mathrm{C}-\mathrm{O}$ out-of-plane bonding & \\
\hline 947 & $\mathrm{C}-\mathrm{O}$ and $\mathrm{C}-\mathrm{C}$ streching & \\
\hline 831 & $\mathrm{C}-\mathrm{C}$ bonding & \\
\hline 2922 & $\mathrm{C}-\mathrm{H}$ streching & Copaiba oil and PVA-O ${ }^{[35]}$ \\
\hline 2854 & $\mathrm{CH}_{2}$ asymmetric streching & \\
\hline 1743 & $\mathrm{C}=\mathrm{O}$ streching & \\
\hline 1415 & $\mathrm{C}-\mathrm{H}$ bending & \\
\hline 3274 & $\mathrm{O}-\mathrm{H}$ streching of alcohol & Duotril and PVA-D $\mathrm{D}^{[36,37]}$ \\
\hline $1700-1600$ & $\mathrm{C}=\mathrm{O}$ streching & \\
\hline 1652 & aromatic $\mathrm{C}=\mathrm{C}$ streching & \\
\hline 1236 & $\mathrm{C}-\mathrm{O}$ streching; $\mathrm{C}-\mathrm{O}-\mathrm{H}$ bending & \\
\hline $900-600$ & $\mathrm{C}-\mathrm{H}$ streching of aromatic ring & \\
\hline
\end{tabular}

$1652 \mathrm{~cm}^{-1}, v(-\mathrm{CH})$ from alkyl groups; $1560 \mathrm{~cm}^{-1}, v(\mathrm{C}=\mathrm{C})$; $1413 \mathrm{~cm}^{-1}$, hydroxyl group $\delta(\mathrm{OH}) ; 1380 \mathrm{~cm}^{-1},(\mathrm{CH}+\mathrm{OH})$ group; $1236 \mathrm{~cm}^{-1}, \mathrm{v}(\mathrm{C}-\mathrm{H}) ; 1142 \mathrm{~cm}^{-1}$, stretching vibration related to crystallites formation; $1089 \mathrm{~cm}^{-1}, v(\mathrm{C}-\mathrm{O})$ of secondary alcohols, C-O out-of-plane bonding; $917 \mathrm{~cm}^{-1}$, $v(\mathrm{CO}$ and $\mathrm{CC}$ groups $)$ and $831 \mathrm{~cm}^{-1}, \mathrm{C}-\mathrm{C}$ bonding ${ }^{[28-34]}$. Some of the PVA bands present lower intensity due to presence of 'oil' (PVA-O and PVA-D-O). However, sample PVA-O presented also bands related to copaiba oil. The copaiba oil bands were observed at: $2922 \mathrm{~cm}^{-1}, v(-\mathrm{CH}) ; 2854 \mathrm{~cm}^{-1}$, $v\left(-\mathrm{CH}_{2}\right) ; 1743 \mathrm{~cm}^{-1}, v(-\mathrm{C}=\mathrm{O}) ; 1415 \mathrm{~cm}^{-1}, \delta(-\mathrm{CH})^{[35]}$.

Spectra of the samples PVA and PVA-D (Figure 1(a)) did not show remarkable difference between them, where the only difference would be the PVA bands intensity. The active antibiotic in Duotrill would be enrofloxacin. Its main bands would be at: $3274 \mathrm{~cm}^{-1} v\left(-\mathrm{OH}\right.$ of alcohol); 1700-1600 $\mathrm{cm}^{-1}$ $v(\mathrm{C}=\mathrm{O}) ; 1652 \mathrm{~cm}^{-1} v(\mathrm{C}=\mathrm{C}) ; 1236 \mathrm{~cm}^{-1} v(\mathrm{CO}), v(\mathrm{COH})$; and bands between $900-600 \mathrm{~cm}^{-1} v(-\mathrm{CH} \text { aromatic })^{[36,37]}$.

Samples PVA-D-O displayed the main bands of PVA and copaiba oil, similar to sample PVA-O, although the bands intensity varied (Figure 1(d)). It was expected to observe high intensity of the bands between $3400-2900 \mathrm{~cm}^{-1}$ and $1800-1100 \mathrm{~cm}^{-1}$ with the addition of enrofloxacin ${ }^{[37]}$. This effect was not observed, but there is a band at $871 \mathrm{~cm}^{-1}$ in PVA-D-O sample, that was not observed in PVA, PVA-D or PVA-O samples, indicating a possible interaction between of copaiba oil and Duotrill ${ }^{\circledR}$.

The XRD analysis revealed probable overlapped peaks and they were deconvoluted to distinguish the crystalline amount from the amorphous one, Figure 2. The addition of copaiba oil to PVA altered the XRD spectrum, although the main peak of all spectra is at $2 \theta \sim 39^{\circ}$, a wide peak that apparently is the overlap of different peaks (peaks at $2 \theta=\sim 32^{\circ}, \sim 39^{\circ}$ and $\left.\sim 47^{\circ}\right)$. The main PVA peak $\left(2 \theta \sim 20^{\circ}\right)$ was not identified in the samples ${ }^{[38]}$. Nonetheless, the addition of Duotrill ${ }^{\circledR}$ led to the presence of another peak at $2 \theta \sim 19^{\circ}$, which could be related to the main enrofloxacin peak at $2 \theta \sim 25^{\circ[39,40]}$.

The XRD curves deconvolution, Figure 2 , revealed the peaks at $2 \theta=\sim 32^{\circ}, \sim 39^{\circ}$ (both probably related to crystalline phase) and a wide peak at $2 \theta=\sim 47^{\circ}$ (possibly related to the amorphous phase). The addition of copaiba oil or duotril to PVA altered the chains packing (decreasing the Xc of the samples), but the addition of both revealed a considerable synergic effect on the samples Xc.

The presence of enrofloxacin peak in the XRD spectra of samples could indicate incomplete incorporation of the drug in the PVA gel ${ }^{[41]}$, or even simple physical presence of the loaded material between PVA chains ${ }^{[42]}$. Although the position of the peaks remained similar after loading, altering the samples Xc could indicate interaction between the materials ${ }^{[43]}$. Duotrill ${ }^{\circledR}$ and oil combined diminished the gels degree of crystallinity and there is an interaction between phases revealed by a new band found only in PVA-D-O sample's FTIR.

\subsection{In vitro analysis}

The swelling tests revealed the all samples swelled at least $180 \%$. There was a peak of media uptake at the onset of all curves and the equilibrium swelling degree (ESD) was reach after 1 day of immersion, Figure 3. The condition to occur the ESD is when the swelling forces (media entrance stretches the network) and elastic forces of the network (chains relaxation and crosslinking are responsible for a partial network's contraction) reach the equilibrium $^{[44]}$. PVA gels usually reaches ESD at $37^{\circ} \mathrm{C}$ of approximately $400 \%$ and at least $300 \%{ }^{[4]}$. The samples in this work presented relatively low ESD (evaluated at room temperature). The temperature could have influenced the ESD, increasing it when evaluated at $37^{\circ} \mathrm{C}^{[4,25]}$. The ANOVA 

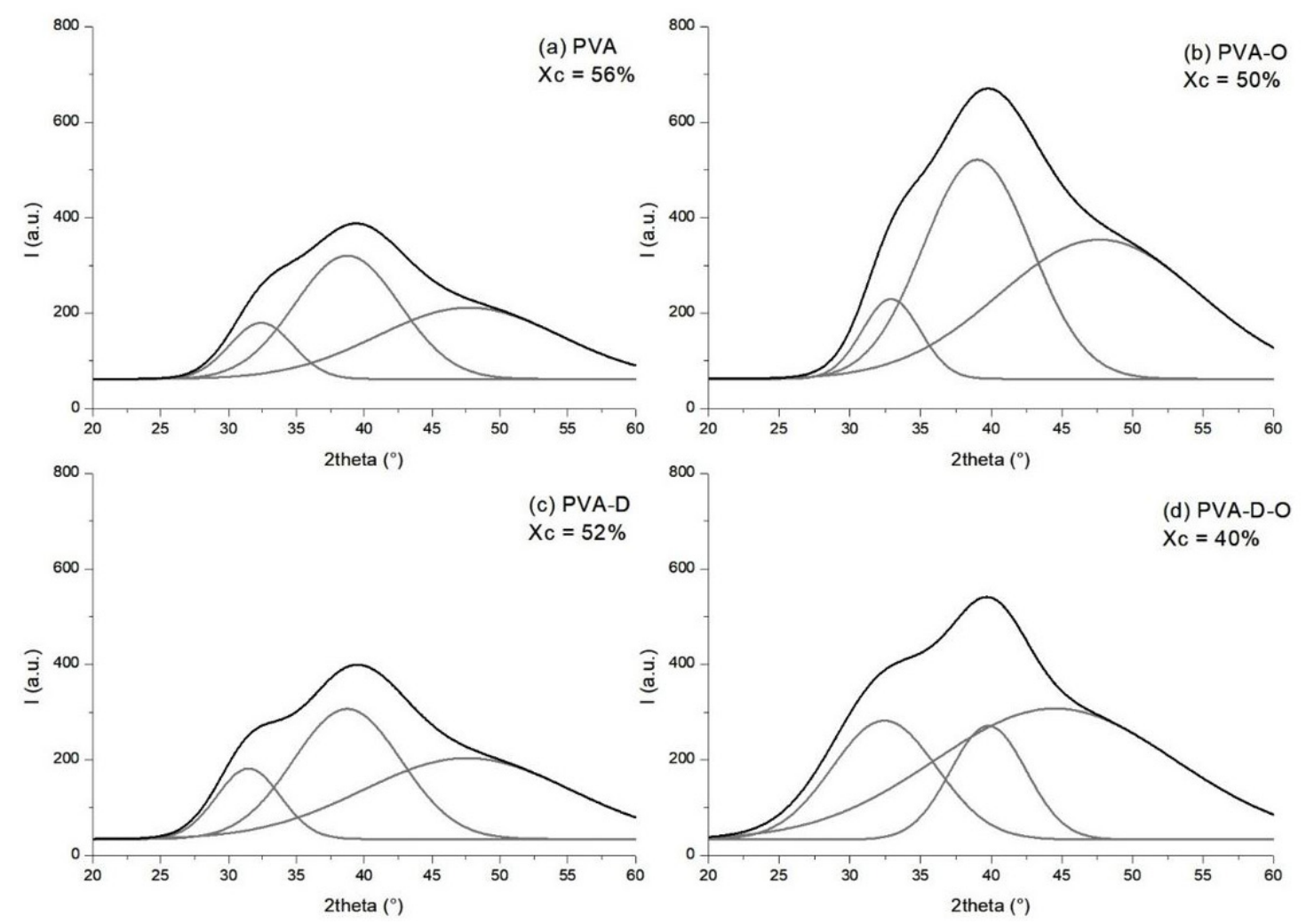

Figure 2. XRD deconvoluted curves of the samples: (a) PVA; (b) PVA-O; (c) PVA-D and (d) PVA-D-O.
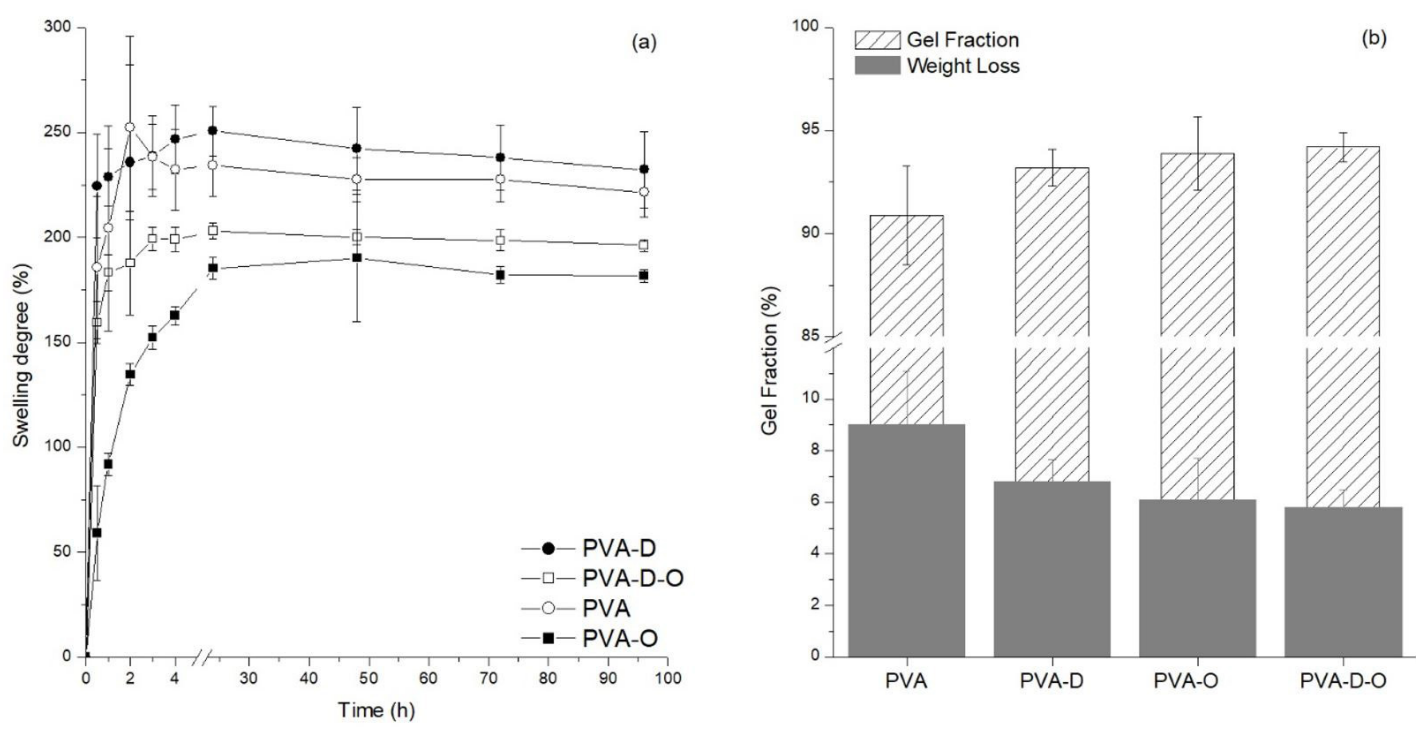

Figure 3. (a) Samples swelling degree and (b) Gel fraction and Weight loss.

analysis on the ESD revealed that samples with oil swelled less than samples without it $(\mathrm{p}<0.05)$. Thereby, copaiba oil alters the samples' hydrophilicity due to its hydrophobic characteristic/ substances ${ }^{[45]}$.

The PVA samples weight loss was higher than the PVA-D-O weight loss, as well as PVA presented lower gel fraction than PVA-D-O $(\mathrm{p}<0.05)$, Figure $3(\mathrm{~b})$. It seems that the PVA chains presented lower mobility and higher inter / intra-connections in PVA-D-O samples. This is an indication that Duotrill ${ }^{\circledR}$ and copaiba oil combined increased the structural stability of the PVA gels ${ }^{[12]}$.

Table 3 shows the results obtained by inhibition of $S$. aureus. The samples loaded with oil reduced the $S$. aureus proliferation considerably, but the highest values 
Table 3. Antimicrobial activity against $S$. aureus.

\begin{tabular}{ccc}
\hline Samples & $\begin{array}{c}\text { Counting mean } \\
\text { (CFU/g) }\end{array}$ & Reduction (\%) \\
\hline PVA & $5.5 \times 10^{6}$ & 0 (reference) \\
PVA-O & $1.1 \times 10^{5}$ & 98 \\
PVA-D & $1.4 \times 10^{3}$ & 99.97 \\
PVA-D-O & $7.5 \times 10^{3}$ & 99.86 \\
\hline
\end{tabular}

of inhibition (total inhibition) was observed in samples containing Duotrill ${ }^{\circledR}$. Classically, copaiba oil ${ }^{[46]}$, as well as enrofloxacin $^{[47]}$, inhibits $S$. aureus, although some organisms could develop resistance to enrofloxacin ${ }^{[48]}$. The gels of the present work seem to have incorporated 'oil' and Duotrill ${ }^{\circledR}$ presenting activity against $S$. aureus.

\section{Conclusions}

Duotrill $^{\circledR}$ and copaiba oil combined diminished the gels degree of crystallinity and there is an interaction between phases revealed by a new band found only in PVA-D-O sample's FTIR. The samples with oil swelled less than samples without it, where copaiba oil altered the samples' hydrophilicity. PVA-D-O presented lower weight loss and higher gel fraction than PVA, indicating the loaded material increased the gels stability. All hydrogels containing copaiba oil and Duotrill ${ }^{\circledR}$ reduced $S$. aureus load, but the combination of both did not result in a greater reduction. Gels loaded with copaiba oil or Duotrill ${ }^{\circledR}$ are potential materials to treat bacterial infections in the veterinary field.

\section{Acknowledgements}

The authors thank CNPq, CAPES and FAPERJ for the support. This work was supported by the Conselho Nacional de Desenvolvimento Científico e Tecnológico [grant number 405922/2016-7].

\section{References}

1. Parry, N. M. A. (2005). Pyelonephritis in small animals. UK Vet, 10(6), 1-5. Retrieved in 2019, May 14, from http://www. parrymedicalwriting.com/wp-content/uploads/2011/09/29pyelonephritis.pdf

2. Galvão, A. L. B. (2010). Pyelonephritis in small animals Revision of the literature. Revista Cientifica Eletrônica de Medicina Veterinária, 15, 1-8. Retrieved in 2019, May 14, from http:// faef.revista.inf.br/imagens_arquivos/arquivos_destaque/ JmZA8rxFKG63OnZ_2013-6-25-16-26-39.pdf

3. Feldkircher, K. C. G. (2014). Intoxicação medicamentosa em animais domésticos. MEDVEP - Revista Científica de Medicina Veterinária - Pequenos Animais e Animais de Estimação, 1, 14-18. Retrieved in 2019, May 14, from: revista.faciplac.edu. br/index.php/Revet/article/download/122/68

4. Oliveira, R. N., McGuinness, G. B., Rouze, R., Quilty, B., Cahill, P., Soares, G. D. A., \& Thiré, R. M. S. M. (2015). PVA hydrogels loaded with a Brazilian propolis for burn wound healing applications. Journal of Applied Polymer Science, 132, 1-12. https://doi.org/10.1002/app.42129.

5. Stauffer, S. R., \& Peppast, N. A. (1992). Poly(vinyl alcohol) hydrogels prepared by freezing-thawing cyclic processing. Polymer, 33(18), 3932-3936. http://dx.doi.org/10.1016/00323861(92)90385-A.
6. Monteiro, M. M. C. (2014). Sintese de hidrogéis biocompativeis para encapsulamento de fármacos (Master's thesis). Universidade de Coimbra, Coimbra.

7. Liu, Y., Geever, L. M., Kennedy, J. E., Higginbotham, C. L., Cahill, P. A., \& McGuinness, G. B. (2010). Thermal behavior and mechanical properties of physically crosslinked PVA/ Gelatin hydrogels. Journal of the Mechanical Behavior of Biomedical Materials, 3(2), 203-209. http://dx.doi.org/10.1016/j. jmbbm.2009.07.001. PMid:20129419.

8. Dragan, E. S. (2014). Design and applications of interpenetrating polymer network hydrogels. Chemical Engineering Journal, 243, 572-590. http://dx.doi.org/10.1016/j.cej.2014.01.065.

9. Jensen, B. E., Dávila, I., \& Zelikin, A. N. (2016). Poly(vinyl alcohol) physical hydrogels: matrix-mediated drug delivery using spontaneously eroding substrate. The Journal of Physical Chemistry B, 120(26), 5916-5926. http://dx.doi.org/10.1021/ acs.jpcb.6b01381. PMid:26958864.

10. Marques, S. C. C. (2011). Libertação de ibuprofeno de hidrogéis de PVA contendo porfirinas (Master's thesis). Universidade de Coimbra, Coimbra.

11. Muriel-Galet, V., Cerisuelo, J. P., López-Carballo, G., Lara, M., Gavara, R., \& Hernández-Muñoz, P. (2012). Development of antimicrobial films for microbiological control of packaged salad. International Journal of Food Microbiology, 157(2), 195-201. http://dx.doi.org/10.1016/j.ijfoodmicro.2012.05.002. PMid:22633535.

12. Brandelero, R. P., Almeida, F. M., Alfaro, A. (2015). The microstructure and properties of starch-polyvinyl alcohol-alginate films with copaiba and lemongrass oils. Quimica Nova, 38(7), 910-916. http://dx.doi.org/10.5935/0100-4042.20150098.

13. Ribeiro-Santos, R., Andrade, M., \& Sanches-Silva, A. (2017). Application of encapsulated essential oils as antimicrobial agents in food packaging. Current Opinion in Food Science, 14, 78-84. http://dx.doi.org/10.1016/j.cofs.2017.01.012.

14. Kavoosi, G., Bordbar, Z., Dadfar, S. M., \& Dadfar, S. M. M. (2017). Preparation and characterization of a novel gelatinpoly(vinyl alcohol) hydrogel film loaded with Zataria multiflora essential oil for antibacterial-antioxidant wound-dressing applications. Journal of Applied Polymer Science, 134, 1-8. https://doi.org/10.1002/app.45351.

15. Phan The, D., Debeaufort, F., Voilley, A., \& Luu, D. (2009). Influence of hydrocolloid nature on the structure and functional properties of emulsified edible films. Food Hydrocolloids, 23(3), 691-699. http://dx.doi.org/10.1016/j.foodhyd.2008.05.006.

16. Sachetti, C. G., Carvalho, R. R., Paumgartten, F. J., Lameira, O. A., \& Caldas, E. D. (2011). Developmental toxicity of copaiba tree (Copaifera reticulata Ducke, Fabaceae) oleoresin in rat. Food and Chemical Toxicology, 49(5), 1080-1085. http:// dx.doi.org/10.1016/j.fct.2011.01.015. PMid:21266184.

17. Veiga Junior, V. F., \& Pinto, A. C. (2002). The Copaifera L. genus. Quimica Nova, 25(2), 273-286. http://dx.doi.org/10.1590/ S0100-40422002000200016.

18. Veiga Junior, V. F., Rosas, E. C., Carvalho, M. V., Henriques, M. G., \& Pinto, A. C. (2007). Chemical composition and anti-inflammatory activity of copaiba oils from Copaifera cearensis Huber ex Ducke, Copaifera reticulata Ducke and Copaifera multijuga Hayne - a comparative study. Journal of Ethnopharmacology, 112(2), 248-254. http://dx.doi.org/10.1016/j. jep.2007.03.005. PMid:17446019.

19. Tincusi, B. M., Jiménez, I. A., Bazzocchi, I. L., Moujir, L. M., Mamani, Z. A., Barroso, J. P., Ravelo, A. G., \& Hernández, B. V. (2002). Antimicrobial terpenoids from the oleoresin of the Peruvian Medicinal Plant Copaifera paupera. Planta Medica, 68(9), 808-812. http://dx.doi.org/10.1055/s-2002-34399. PMid:12357392. 
20. Laboratórios Duprat. (2017). Ficha técnica: Duotrill $50 \mathrm{mg}$ comprimidos. Rio de Janeiro: Laboratórios Duprat. Retrieved in 2019, March 14, from: https://www.laboratoriosduprat.com. br

21. Vancutsem, P. M., Babish, J. G., \& Schwark, W. S. (1990). The fluorquinolone antimicrobials: structure, antimicrobial activity, pharmacokinetics, clinical use in domestic animals and toxicity. The Cornell Veterinarian, 80(2), 173-186. PMid:2180631. Retrieved in 2019, May 14, from: https://babel.hathitrust.org/ cgi/pt?id=coo.31924056935673; view=1up;seq=187

22. Barcellos, H. H. A., Oliveira, S. T., Alves, L. P., Motta, A. C., Rocha, F. R., \& Brun, M. V. (2006). Intoxicação por enrofloxacina em um cão da raça Pinscher Miniatura: relato de caso. Arquivo Brasileiro de Medicina Veterinária e Zootecnia, 58(1), 39-43. http://dx.doi.org/10.1590/S0102-09352006000100007.

23. Solanki, T. H., Patel, J., Varia, R. D., Bhavsar, S. K., Vihol, P. D., \& Modi, F. D. (2016). In Vitro release and pharmacokinetics of enrofloxacin PHBV microsphere in rats. International Journal of Science. Environmental Technology, 5(4), 25222531. Retrieved in 2019, May 14, from: http://www.ijset.net/ journal/1191.pdf

24. Azrina, Z. A. Z., Beg, M. D. H., Yunus, R. M., \& Ramli, R. (2017). Nano crystal cellulose incorporated poly vinyl alcohol (PVA) hydrogel for industrial waste water treatment. Australian Journal of Basic and Applied Sciences, 11(3), 137142. Retrieved in 2019, May 14, from: http://www.ajbasweb. com/old/ajbas/2017/Special\%20issue\%20ICCEIB/137-142. pdf

25. Oliveira, R. N., Rouzé, R., Quilty, B., Alvez, G. G., Thiré, R. M., \& McGuinness, G. B. (2013). Mechanical properties and in vitro chracterization of polyvinyl alcohol-nano-silver hydrogel wound dressings. Interface Focus, 4(1), 1-11. http:// dx.doi.org/10.1098/rsfs.2013.0049.

26 Costa, D. R. (2012). Hidrogéis de PVA-NaCMC para aplicação em curativos (Graduation degree). Universidade Federal do Rio de Janeiro, Rio de Janeiro.

27. Alcântara, M. T. S., Brant, A. J. C., Giannini, D. R., Pessoa, J. O. C. P., Andrade, A. B., Riella, H. G., \& Lugão, A. B. (2012). Influence of dissolution processing of PVA blends on the characteristics of their hydrogels synthesized by radiation - Part I: gel fraction, swelling, and mechanical properties. Radiation Physics and Chemistry, 81(9), 1465-1470. http:// dx.doi.org/10.1016/j.radphyschem.2012.01.048.

28. Hua, S., Ma, H., Li, X., Yang, H., \& Wang, A. (2010). pHsensitive sodium alginate/poly(vinyl alcohol) hydrogel beads prepared by combined $\mathrm{Ca}^{2+}$ crosslinking and freeze-thawing cycles for controlled release of diclofenac sodium. International Journal of Biological Macromolecules, 46(5), 517-523. http:// dx.doi.org/10.1016/j.ijbiomac.2010.03.004. PMid:20223260.

29. Parsa, P., Paydayesh, A., \& Davachi, S. M. (2019). Investigating the effect of tetracycline addition on nanocomposite hydrogels based on polyvinyl alcohol and chitosan nanoparticles for specific medical applications. International Journal of Biological Macromolecules, 121, 1061-1069. http://dx.doi.org/10.1016/j. ijbiomac.2018.10.074. PMid:30342143.

30. Lee, J. M., Sultan, M. T., Kim, S. H., Kumar, V., Yeon, Y. K., Lee, O. J., \& Park, C. H. (2017). Artificial auricular cartilage using silk fibroin and polyvinyl alcohol hydrogel. International Journal of Molecular Sciences, 18(8), 1-15. http://dx.doi. org/10.3390/ijms18081707. PMid:28777314.

31. Reis, E. F., Campos, F. S., Lage, A. P., Leite, R. C., Heneine, L. G., Vasconcelos, W. L., Lobato, Z. I. P., \& Mansur, H. S. (2006). Synthesis and characterization of poly(vinyl alcohol) hydrogels and hybrids for rMPB70 protein adsorption. Materials Research, 9(2), 185-191. http://dx.doi.org/10.1590/S151614392006000200014 .
32. Choo, K., Ching, Y. C., Chuah, C. H., Julai, S., \& Liou, N. S. (2016). Preparation and characterization of polyvinyl alcoholchitosan composite films reinforced with cellulose nanofiber. Materials (Basel), 9(8), 1-16. http://dx.doi.org/10.3390/ ma9080644. PMid:28773763.

33. Raju, C. L., Rao, J. L., Reddy, B. C. V., \& Veera Brahmam, K. (2007). Thermal and IR studies on copper doped polyvinyl alcohol. Bulletin of Materials Science, 30(3), 215-218. http:// dx.doi.org/10.1007/s12034-007-0038-1.

34. Campos, E., Coimbra, P., \& Gil, M. H. (2013). An improved method for preparing glutaraldehyde cross-linked chitosanpoly(vinyl alcohol) microparticles. Polymer Bulletin, 70(2), 549-556. http://dx.doi.org/10.1007/s00289-012-0853-4.

35. Pinheiro, J. G. O., Tavares, E. A., Silva, S. S. D., Félix Silva, J., Carvalho, Y. M. B. G., Ferreira, M. R. A., Araújo, A. A. S., Barbosa, E. G., Fernandes Pedrosa, M. F., Soares, L. A. L., Azevedo, E. P., Veiga Júnior, V. F. D., \& Lima, Á. A. N. (2017). Inclusion complexes of copaiba (Copaifera multijuga Hayne) oleoresin and cyclodextrins: physicochemical characterization and anti-inflammatory activity. International Journal of Molecular Sciences, 18(11), 1-18. http://dx.doi.org/10.3390/ ijms18112388. PMid:29156553.

36. - Ben Salem, S., Mezni, M., Errami, M., Amine, K. M., Salghi, R., Ismat, H. A., Chakir, A., Hammouti, B., Messali, M., \& Fattouch, S. (2015). Degradation of enrofloxacin antibiotic under combined ionizing radiation and biological removal technologies. International Journal of Electrochemical Science, 10, 3613-3622.

37. Yan, W., Zhang, J., \& Jing, C. (2013). Adsorption of Enrofloxacin on montmorillonite: two-dimensional correlation ATR/FTIR spectroscopy study. Journal of Colloid and Interface Science, 390(1), 196-203. http://dx.doi.org/10.1016/j.jcis.2012.09.039. PMid:23079042.

38. Puspitasari, T., Raja, K. M. L., Pangerteni, D. S., Patriati, A., \& Putra, E. G. R. (2012). Structural organization of poly(vinyl alcohol) hydrogels obtained by freezing/thawing and $\gamma$-irradiation processes: a small-angle neutron scattering (SANS) study. Procedia Chemistry, 4, 186-193. http://dx.doi. org/10.1016/j.proche.2012.06.026.

39. Gutierrez, L., Miranda-Calderon, J. E., Garcia-Gutierrez, P., \& Sumano, H. (2015). Physicochemical characterization and pharmacokinetics in broiler chickens of a new recrystallized enrofloxacin hydrochloride dihydrate. Journal of Veterinary Pharmacology and Therapeutics, 38(2), 183-189. http://dx.doi. org/10.1111/jvp.12153. PMid:25224691.

40. Thangadurai, S., Shukla, S. K., Srivastava, A. K., \& Anjaneyulu, Y. (2003). X-ray powder diffraction patterns for certain fluoroquinolone antibiotic drugs. Acta Pharmaceutica (Zagreb, Croatia), 53(4), 295-303. PMid:14769236.

41. Mabrouk, M., Mostafa, A. A., Oudadesse, H., Mahmoud, A. A., \& El-Gohary, M. I. (2013). Effect of ciprofloxacin incorporation in PVA and PVA bioactive glass composite scaffolds. Ceramics International, 40(3), 4833-4845. https:// doi.org/10.1016/j.ceramint.2013.09.033

42. Malik, N. S., Ahmad, M., \& Minhas, M. U. (2017). Cross-linked $\beta$-cyclodextrin and carboxymethyl cellulose hydrogels for controlled drug delivery of acyclovir. PLoS One, 12(2), 1-17. http://dx.doi.org/10.1371/journal.pone.0172727

43. Wong, R. S. H., \& Dodou, K. (2017). Effect of drug loading method and drug physicochemical properties on the material and drug release properties of poly (ethylene oxide) hydrogels for transdermal delivery. Polymers, 9(7), 1-29. http://dx.doi. org/10.3390/polym9070286. PMid:30970963.

44. Ottenbrite, R. M., Park, K., \& Okano, T. (2010). Biomedical applications of hydrogels handbook. London: Springer. 
45. Brandelero, R. P. H., Grossmann, M. V., \& Yamashita, F. (2013). Hidrofilicidade de filmes de amido/poli(butileno adipato co-tereftalato) (Pbat) adicionados de tween 80 e óleo de soja. Polimeros Ciência e Tecnologia, 23(2), 270-275. http:// dx.doi.org/10.4322/S0104-14282013005000011.

46. Pereira, N. C. M., Mariscal, A. G., Nepoceno, K. L. P. C., Silva, V. C. C. R., Fernandes, H. M., \& Vivi, V. K. (2018). Antimicrobial activity of natural/commercial copaiba oil-resin against standard strains. Journal Health NPEPS, 3(2), 527-539. http://dx.doi.org/10.30681/252610103189.

47. Nunes, S. F., Bexiga, R., Cavaco, L. M., \& Vilela, C. L. (2007). Technical note: antimicrobial susceptibility of Portuguese isolates of Staphylococcus aureus and Staphylococcus epidermidis in subclinical bovine mastitis. Journal of dairy science, 90(7), 3242-3246. http://dx.doi.org/10.3168/jds.2006739. PMid:17582107.

48. Wang, W., Lin, X., Jiang, T., Peng, Z., Xu, J., Yi, L., Li, F., Fanning, S., \& Baloch, Z. (2018). Prevalence and characterization of Staphylococcus aureus cultured from raw milk taken from dairy cows with mastitis in Beijing, China. Frontiers in Microbiology, 9, 1123. http://dx.doi.org/10.3389/ fmicb.2018.01123. PMid:29988423.

Received: May 14, 2019

Revised: Aug. 26, 2019

Accepted: Aug. 26, 2019 